\title{
Potensi Antibakteri Empat Species Lactobacillus dari Susu Fermentasi Terhadap Mikroba Patogen
}

\author{
Zaraswati Dwyana $^{1}$, Rachmat Kosman ${ }^{2}$ dan Irmayanti Usman ${ }^{2}$ \\ ${ }^{1}$ Departemen Biologi, Fakultas Matematika dan Ilmu Pengetahuan Alam, \\ Universitas Hasanuddin, Makassar, 90245 \\ ${ }^{2}$ Fakultas Farmasi, Universitas Muslim Indonesia \\ email: zaraswatidwyana@gmail.com
}

\begin{abstract}
Abstrak
Salah satu kelompok bakteri asam laktat yang banyak ditemukan pada susu fermentasi adalah Lactobacillus bulgaricus, Lactobacillus casei, Lactobacillus spp dan Lactobacillus acidophilus. Dalam studi ini ketiga species digabungkan untuk mengetahui efektifitasnya sebagai probiotik yang mampu menghasilkan senyawa antibakteri terhadap bakteri patogen. Uji antibakteri dilakuan dengan metode difusi agar pada medium Glukosa Nutrient Agar. Bkateri patogen yang diujikan adalah Escherichia coli, Staphylococcus aureus dan Candida albicans. Hasil uji antibakteri terhadap kombinasi kultur diketahui bahwa Lactobacillus bulgaricus_dengan Lactobacillus casei, Lactobacillus bulgaricus dengan Lactobacillus sp, Lactobacillus acidophilus dengan Lactobacillus casei, Lactobacillus achidophilus dengan Lactobacillus sp, Lactobacillus achidophilus dengan Lactobacillus bulgaricus, Lactobacillus sp dengan Lactobacillus casei dari dapat menghambat pertumbuhan Staphylococccus aureus, Escherichia coli dan Candida albicans. Diameter zona hambatan yang terbesar adalah variasi Lactobacillus bulgaricus dengan Lactoabacillus spp terhadap Candida albicans sebesar 19,33 mm, variasi Lactobacillus acidophilus dengan Lactobacillus casei terhadap Staphylococcus aureus sebesar 19,83 mm, sedangkan variasi Lactobacillus lactis dengan Lactobacillus casei terhadap Escherichia coli sebesar 29,49 $\mathrm{mm}$.
\end{abstract}

Kata kunci: antibakteri, fermentasi, Lactobacillus

\section{PENDAHULUAN}

Salah satu kelompok bakteri yang memegang peranan penting dalam industri fermentasi adalah bakteri asam laktat. Beberapa jenis bakteri asam laktat ada yang menjadi penduduk asli saluran pencernaan, enteric lactic acid bacteria, di antaranya Bifidobacterium bifidum, Bifidobacterium longum, Bifidobacterium infantis (pada bayi), Bifidobacterium adolescentris yang menempati usus besar manusia, Lactobacillus acidophilus, Lactobacillus gasseri, Lactobacillus crispatus, Lactobacillus johnsonii, Lactobacillus salivarius, Lactobacillus ruminis, Lactobacillus vitulinus dan Lactobacillus reuteri yang hidup dalam usus halus (Surono,2004).

Bakteri asam laktat tersebut digunakan dalam memfermentasikan susu menjadi yoghurt yang merupakan produk yang sangat besar manfaatnya bagi kesehatan karena kaya akan nutrient, 
protein serta vitamin dan mineral. Efek antimikroba bakteri asam laktat telah diperhitungkan sehingga dapat memperpanjang masa simpan berbagai jenis bahan makanan melalui proses fermentasi. Efek pengawetan bakteri asam laktat utama adalah karena dihasilkan asam laktat yang menurunkan nilai keasaman atau PH bahan pangan. Disamping itu dihasilkan juga senyawa antimikrobial yaitu peptida yang disintesis dalam ribosoma, dikenal sebagai bakteriosin .

Beberapa jenis bakteri asam laktat menghasilkan bakteriosin, suatu peptida yang bersifat antibakteri, toksin yang berupa protein yang dapat mencegah pertumbuhan bakteri sejenis. Kriteria bakteriosin yang dihasilkan oleh bakteri gram positif, yaitu suatu jenis protein, bersifat bakterisidal tidak hanya bakteriostatik, mencegah pertumbuhan bakteri sejenis, dan mempunyai tempat pelekatan spesifik bagi patogen, yang membedakannya dengan senyawa antimikroba lainnya (Surono, 2004).

\section{METODE PENELITIAN}

\section{Pembuatan variasi bakteri asam laktat}

a. Penyiapan sampel. Sampel yang digunakan adalah isolat Bakteri Asam Laktat yang ditumbuhkan dalam medium MRS Broth diinkubasi pada suhu $37^{\circ} \mathrm{C}$ selama 2 × 24 jam kemudian dibuat variasi bakteri asam laktat tersebut.

b. Variasi Bakteri Asam Laktat

Sampel A : Lactobacillus lactis + Lactobacillus casei

Sampel B : Lactobacillus lactis + Lactobacillus bulgaricus

Sampel C : Lactobacillus lactis + Lactobacillus acidophilus

Sampel D : Lactobacillus lactis + Lactobacillus spp

Sampel E : Lactobacillus lactis + Lactobacillus casei

Sampel F : Lactobacillus casei + Lactobacillus casei

Sampel G : Lactobacillus casei + Lactobacillus spp

Sampel H : Lactobacillus casei + Lactobacillus bulgaricus

Sampel I : Lactobacillus casei + Lactobacillus acidophilus

Sampel J : Lactobacillus bulgaricus + Lactobacillus casei

Sampel K : Lactobacillus bulgaricus + Lactobacillus spp

Sampel L : Lactobacillus acidophilus + Lactobacillus casei

Sampel M : Lactobacillus acidophilus + Lactobacillus spp

Sampel N : Lactobacillus acidophilus + Lactobacillus bulgaricus

Sampel O : Lactobacillus spp + Lactobacillus casei

\section{Penyiapan mikroba uji}

a. Peremajaan kultur murni mikroba uji

Mikroba uji (Candida albicans, Esherichia coli dan Staphylococcus aureus) dari biakan murni masing-masing diambil 1 ose. Kemudian diinokulasikan dengan cara digoreskan pada medium agar miring kemudian diinkubasikan pada suhu $37^{\circ} \mathrm{C}$ selama 24 jam dan untuk jamur pada suhu kamar selama 72 jam.

b. Pembuatan suspensi mikroba uji 
Mikroba uji (Candida albicans, Escherichia coli dan Staphylococcus aureus) yang berumur 24 jam disuspensikan dengan larutan $\mathrm{NaCl}$ fisiologis $0,9 \%$ kemudian diukur serapan suspensi biakan ini dengan spektrofotometer pada panjang gelombang $580 \mathrm{~nm}$.

\section{Pengujian aktivitas antibakteri}

Medium Glukosa Nutrien Agar (GNA) steril yang telah dipanaskan dan disterilkan kemudian didinginkan hingga suhu sekitar $40-45^{\circ} \mathrm{C}$ lalu dituang secara aseptis ke dalam cawan petri steril sebanyak $10 \mathrm{ml}$ sebagai base layer dan dibiarkan memadat. Setelah itu $5 \mathrm{ml}$ medium GNA disuspensikan dengan $1 \mathrm{ml}$ suspensi bakteri uji kemudian dituang ke dalam cawan petri yang telah berisi base layer dan dibiarkan hingga setengah memadat sebagai seed layer. Diletakkan pencadang di atas permukaan seed layer dengan hati-hati, kemudian pencadang diisi dengan variasi Lactobacillus $s p$ sebanyak $0,2 \mathrm{ml}$ selanjutnya diinkubasi pada suhu $37^{\circ} \mathrm{C}$ selama 24-48 jam dalam inkubator dan untuk jamur pada suhu kamar. Kemudian dilakukan pengamatan dan pengukuran zona hambatan yang terbentuk. Perlakuan diulangi sebanyak 3 kali.

\section{HASIL DAN PEMBAHASAN}

Telah dilakukan pengamatan dan pengukuran zona hambatan pada uji aktifitas antimikroba variasi jenis Lactobacillus sp terhadap Esherichia coli dan Staphylococcus aereus dengan masa inkubasi 24 jam dan Candida albicans dengan masa inkubasi 72 jam (Tabel 1).

Tabel 1. Hasil Pengukuran Diameter Rata-Rata Zona Hambatan AktivitasAntimikroba Variasi Jenis Lactobacillus sp Terhadap Mikroba Uji

\begin{tabular}{|c|c|c|c|c|}
\hline \multirow{2}{*}{ No } & \multirow{2}{*}{$\begin{array}{c}\text { Variasi Bakteri } \\
\text { Asam Laktat }\end{array}$} & \multicolumn{3}{|c|}{$\begin{array}{c}\text { Zona penghambatan terhadap } \\
\text { mikroba uji (mm) }\end{array}$} \\
\cline { 2 - 5 } & Esherichia coli & $\begin{array}{c}\text { Staphylococcus } \\
\text { aereus }\end{array}$ & $\begin{array}{c}\text { Candida } \\
\text { albicans }\end{array}$ \\
\hline 1 & A & 0 & 15,83 \\
3 & B & 0 & 0 & 0 \\
4 & C & 24,16 & 0 & 15,83 \\
5 & 19,33 & 15,50 & 0 \\
6 & D & 29,49 & 18,99 & 0 \\
7 & E & 25,00 & 0 & 14,50 \\
8 & F & 22,50 & 16,49 & 15,83 \\
9 & G & 24,50 & 0 & 14,66 \\
10 & H & 28,66 & 0 & 16,66 \\
11 & I & 27,33 & 19,00 & 17,83 \\
12 & J & 18,66 & 14,49 & 19,33 \\
13 & K & 21,66 & 19,83 & 18,00 \\
14 & L & 23,83 & 18,16 & 17,99 \\
15 & M & 24,16 & 18,83 & 18,66 \\
\hline
\end{tabular}

Keterangan :

$\mathrm{A}=$ Lactobacillus lactis dengan Lactobacillus casei 
$\mathrm{B}=$ Lactobacillus lactis dengan Lactobacillus bulgaricus

$\mathrm{C}=$ Lactobacillus lactis dengan Lactobacillus achidophilus

$\mathrm{D}=$ Lactobacillus lactis dengan Lactobacillus $s p$

$\mathrm{E}=$ Lactobacillus lactis dengan Lactobacillus casei

$\mathrm{F}=$ Lactobacillus casei dengan Lactobacillus casei

$\mathrm{G}=$ Lactobacillus casei dengan Lactobacillus $s p$

$\mathrm{H}=$ Lactobacillus casei dengan Lactobacillus bulgaricus

$\mathrm{I}=$ Lactobacillus casei dengan Lactobacillus achidophilus

$\mathrm{J}=$ Lactobacillus bulgaricus dengan Lactobacillus casei

$\mathrm{K}=$ Lactobacillus bulgaricus dengan Lactobacillus $s p$

$\mathrm{L}=$ Lactobacillus achidophilus dengan Lactobacillus casei

$\mathrm{M}=$ Lactobacillus achidophilus dengan Lactobacillus sp

$\mathrm{N}=$ Lactobacillus achidophilus dengan Lactobacillus bulgaricus

$\mathrm{O}=$ Lactobacillus sp dengan Lactobacillus casei

Penelitian ini telah dilakukan dengan tujuan untuk mengetahui kemampuan dari beberapa variasi jenis Lactobacillus $s p$ dalam menghambat pertumbuhan mikroba patogen yang diketahui dapat mengganggu saluran pencernaan dalam hal ini digunakan Candida albicans, Escherichia coli dan Staphylococcus aureus. Hasil penelitian dari variasi bakteri asam laktat menunjukkan hasil yang sangat efektif dalam menghambat bakteri E.coli tapi kurang efektif untuk C.albicans.

Suspensi mikroba yang digunakan sebanyak 0,02 $\mathrm{ml}$ karena pada kadar tersebut pertumbuhan koloni merata dan homogen setelah diinkubasi selama 24 jam atau 48 jam. Ini sesuai dengan pendapat Capucino, J.G dan Sherman, N (1983), yang menyatakan bahwa ukuran diameter zona hambatan pada uji daya hambat suatu antibiotik tergantung beberapa faktor, salah satu diantaranya jumlah mikroorganisme yang diinokulasikan pada media uji.

Dari hasil pengujian aktivitas antimikroba yang dilakukan diperoleh rata-rata diameter zona hambatan yang terbentuk memperlihatkan hambatan yang terbesar adalah variasi Lactobacillus bulgaricus dengan Lactobacillus sp terhadap Candida albicans sebesar 19,33 mm, Staphylococcus aureus adalah variasi Lactobacillus acidophilus dengan Lactobacillus casei sebesar 19,83 mm sedangkan untuk bakteri uji Escherichia coli adalah variasi Lactobacillus lactis dengan Lactobacillus casei sebesar 29,49 mm.
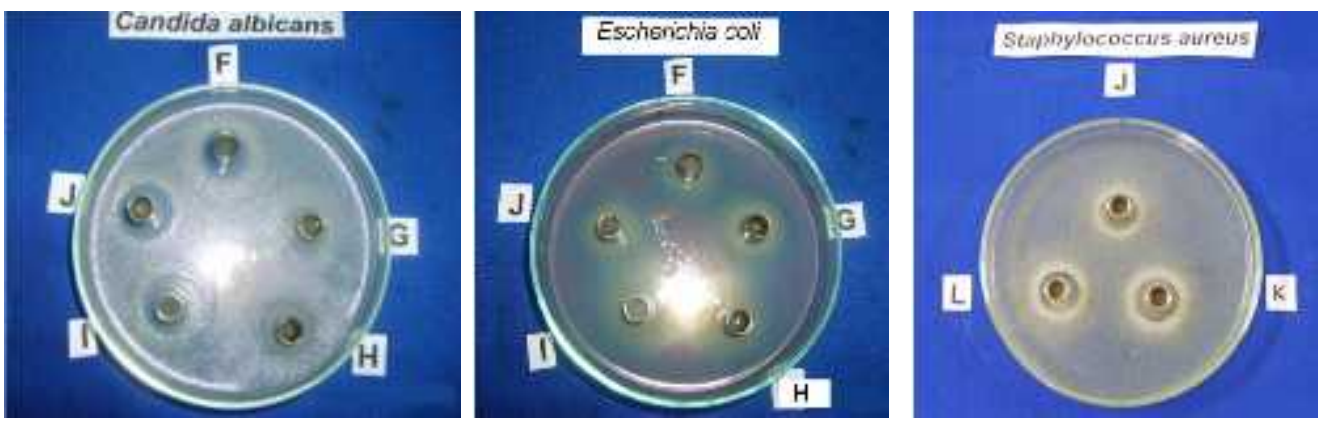

Gambar 1. Uji antibakteri dari variasi bakteri asam laktat terhadap tiga bakteri patogen

Hasil ini sesuai dengan yang dikemukakan oleh Surono, I, (2004) bahwa antimikroba yang diproduksi oleh Laktobacillus bulgaricus berupa senyawa helveticin dan lacticin B dan yang diproduksi oleh Lactobacillus sp berupa senyawa bakteriosin. Variasi kedua senyawa tersebut 
bersifat sinergis dalam menghambat Candida albicans. Lactobacillus achidophilus menurut Rachmawati (2005) menghasilkan Lactacin B dan acidocin dan yang diproduksi oleh Lactobacillus casei dari yakult ${ }^{\mathbb{B}}$ menghasilkan Plantaricin dan casseicin. Variasi kedua senyawa tersebut bersiafat sinergis dalam menghambat Staphylococcus aureus. Sedangkan Lactobacillus lactis menurut Rachmawati (2005) menghasilkan lacticin dan lactobacillus casei menghasilkan plantaricin dan casseicin. Variasi kedua senyawa tersebut bersifat sinergis dalam menghambat Escherichla coli. Siafat sinergis ini menunjukkan besarnya diameter hambatan yang terbentuk.

Lactobacillus bulgaricus dan Lactobacillus lactis tidak mampu menghambat Escherichia coli dan Staphylococcus dan tidak terdapat zona hambatan. Demikian pula dengan variasi Lactobacillus lactis dan Lactobacillus casei tidak mampu menghambat Escherichia coli dan Staphylococcus . Lactobacillus lactis dan Lactobacillus acidophilus ,Lactobacillus casei dan lactobacillus casei, Lactobacillus casei dan Lactobacillus bulgaricus serta Lactobacillus casei dan lactobacillus acidophilus tidak mampu menghambat Staphylococcus. Hal ini dapat disebabkan bahwa senyawa antimikroba yang dihasilkan tidak dapat menghambat bakteri uji karena dapat terjadi adanya sifat anatagonisme dari kedua mikroba tersebut (Surono,I, 2004)

\section{KESIMPULAN}

Berdasarkan hasil penelitian yang diperoleh maka dapat diambil kesimpulan bahwa variasi Lactobacillus sp yang memberikan zona hambatan terbesar adalah Lactobacillus bulgaricus dengan Lactobacillus sp terhadap Candida albicans sebesar 19,33 mm, Lactobacillus achidophilus dengan Lactobacillus casei dari yakult ${ }^{\circledR}$ terhadap Staphylococcus aureus sebesar 19,83 mm sedangkan Lactobacillus lactis dengan Lactobacillus casei terhadap Escherichia coli sebesar 29,49 mm.

\section{DAFTAR PUSTAKA}

Buchanan.R.E, and Gibbons.N.E.,1974, Bergey's Manual of Determinative Bacteriology, $8^{\text {th }}$ Edition, The Williams and Wilkins Company,United States of America.

Surono, I., 2004. Probiotik Susu Fermentasi dan Kesehatan, PT. Tri Cipta Karya, Jakarta.

Rachmawati I,Sunarto dan R.Setyaningsih.2005. Uji antibakteri bakteri asam laktat asal asinan sawi terhadap bakteri patogen. Bioteknologi 2(2),43-48. 